\title{
CT ALKALMAZÁSI LEHETÖSÉGEI AZ ÉPÍTŐANYAGOK VIZSGÁLATÁNÁL
}
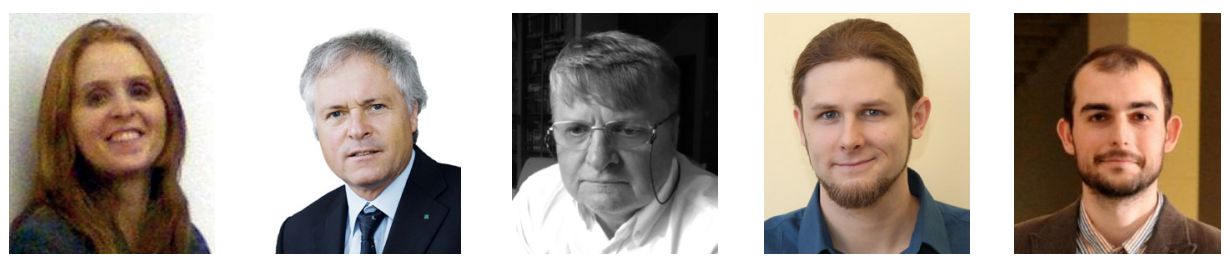

DOI: $10.32969 /$ VB.2018.4.3

Dr. Majorosné Lublóy Éva Eszter - Dr. Balázs L. György - Földes Tamás - Dr. Kapitány Kristóf - Hlavicka Viktor

Az építöanyagok belső szerkezetének ismerete számunkra nagyon fontos, hiszen az anyagok tulajdonságait és tartósságát az nagymértékben befolyásolja. Az anyagok belsö szerkezete sok kiegészitö információt tartalmaz, melynek vizsgálata analitikai módszerekkel csak részben lenne lehetséges.

A komputertomográfiás (CT) felvételeken a vizsgálat tárgya szeletekre bontva látható. Az adatmátrixból elöállitott kép tulajdonképpen egy sürüségtérkép az adott anyagokról. Ezen sürüségképen jól kirajzolódnak a vizsgált tárgy különbözö sürüségü elemei, ezáltal különbözö sürüségü összetevői is azonosithatóak. A szeletek egymás utáni lejátszásával gyakorlatilag bele láthatunk az anyag szerkezetébe, de három dimenzióban is ábrázolhatjuk a vizsgált anyagot.

A cikk keretein belül szeretnénk áttekinteni, hogy a CT vizsgálatok hogyan lehetnek célszerüen használhatóak az épitöanyagok vizsgálatai során.

Kulcsszavak: anyagvizsgálat, CT, anyagszerkezet, roncsolásmentes vizsgálat

\section{BEVEZETÉS}

Az építőanyagok kis léptékü ( $\mathrm{mm}$ ) térbeli belső felépítéséről nehéz megbízható módon, roncsolásmentesen képet alkotni. Optikai vagy elektron mikroszkóppal roncsolásmentes módon csak felületi kép készíthető. Hagyományos módszerekkel a minta felszeletelése után lehetőség van egy-egy vékony szeletről további képek felvételére is, de ez meglehetősen időigényes, és a szeletek elkészítésekor megváltozhat a minta belső szerkezete, így a háromdimenziós eredeti belső szerkezetre a legtöbb esetben nehéz megbízható módon következtetést levonni. A hagyományos röntgenképek tartalmazzák a teljes háromdimenziós belső szerkezet vetületi képét, azonban ilyen felvételekből nem nyerhető ki a valós háromdimenziós szerkezet. A számítógépes tomográfiával (X-ray computed tomography, CT) lehetővé válik a teljes három-dimenziós belső szerkezetről a képalkotás anélkül, hogy szükség volna minta előkészítésre vagy kémiai fixálásra.

A komputertomográfiás $(\mathrm{CT})$ felvételeken a vizsgálat tárgya szeletekre bontva látható. A CT adatmátrixból vizualizált kép első közelítésben úgy kezelhető, mint egy szeletfelbontásnak megfelelő sürüségtérkép az adott anyagokról. Ezen sürüség képen jól kirajzolódnak a vizsgált tárgy különböző összetevői (adalékanyag szemcsék, pórusok, repedések). A szeletek egymás utáni lejátszásával gyakorlatilag beleláthatunk az anyag szerkezetébe.

Az építőanyagok belső szerkezetének ismerete számunkra nagyon fontos, hiszen az anyagok tulajdonságait és tartósságát az nagymértékben befolyásolja. Ha az anyagok belső szerkezetébe belelátunk és ezáltal megismerjük, akkor sok kiegészítő információt kaphatunk, melyek vizsgálata analitikai módszerekkel csak részben lenne lehetséges.

A cikk keretein belül összefoglaljuk, hogy a CT-vizsgálatok hogyan lehetnek célszerüen használhatóak az építőanyagok vizsgálatai során.

\section{A SZÁMÍTÓGÉPES TOMOGRÁ- FIA (CT) MÜKÖDÉSE}

A szakirodalomban a CT-vizsgálat más néven számítógépes (komputer) tomográfia néven ismeretes, ami a radiológiai diagnosztika egyik ága. A tomográfia szó a szeletelésre utal. A tomográfiás felvételeken a vizsgálat tárgya képzeletbeli szeletekre bontva látható. A komputertomográfia a hagyományos röntgenátvilágítási technika továbbfejlesztése.

A CT-készülékek is röntgensugárzást használnak a felvételek elkészítéséhez, de a sugarak nem filmet exponálnak, hanem detektorok segítségével érzékelik a röntgensugarakat, majd a detektorokból nyert elektromos jelekből számítógép segítségével készül el a rekonstruált keresztmetszeti kép. A tomográfiás felvétel esetében vékony, síkszerü röntgensugárnyalábbal világítják át a vizsgált objektumot. Az objektum mögött elhelyezett detektor egy vonal mentén érzékeli, hogy a sugárnyalábból hol és mennyi nyelődött el. A sugárnyalábbal egy adott síkban több irányból is átvilágítják a testet, és a mért intenzitásgörbékből kibontakozik az adott síkban (szeletben) elhelyezkedő részletek rajza. A síkot ezután arrébb tolják, és újra körbeforgatják. Az eljárás befejeztével a vizsgált test térbeli szerkezete feltérképezhető. „Szerkezeten” itt a röntgensugár áteresztő képesség szempontjából megkülönböztethető részletek, vagyis a különböző sürüségü anyagok elrendeződése értendő (Berényi, Bogner, Horváth, Repa, 1997).

A vizsgálat a szükséges számításokkal együtt néhány perc alatt elvégezhető (Földes, 2011, Buzug, 2008). A teljes kiértékelés további jelentős feladatokat jelent.

A mérési módszer az anyagok eltérő sugárgyengítési tulajdonságain alapul. A $\mu$ sugárgyengítési együttható az anyagra jellemző tulajdonság, ami az anyag sürüségétől és a röntgensugárzás spektrumától függ.

A CT felvételek minden egyes voxelje (térfogategysége) 
egy-egy intenzitásértékkel rendelkezik, ami az adott térfogatelem relatív lineáris sugárgyengítését mutatja (Russ, 2011). A következö lépésben ezeket az értékeket egy skálához rendeljük az alábbi képlet alapján:

$$
H U=\frac{K\left(\mu-\mu_{v i z}\right)}{\mu_{v i z}},
$$

ahol:

HU a Hounsfield-egység (Hounsfield Unit) [-],

$\mathrm{K} \quad$ egy konstans, aminek az értéke 1000 [-],

$\mu \quad$ az adott képpont sugárgyengítési együtthatója,

$\mu_{\text {viz }} \quad$ a víz sugárgyengítési együtthatója.

A skála fix pontjai a víz Hounsfield-értéke, ami 0-ra van felvéve, és a levegő Hounsfield-értéke, ami -1000 Hounsfieldegység. A Hounsfield-értékek értelmezési tartománya általában -1024-től +3071-ig tart, de a modern készülékeken lehetőség van a skála kiterjesztésére, ezáltal részletesebb felosztására is.

Tekintettel arra, hogy a CT ezek alapján csak a sürüségkülönbségek mérésére szolgál, ezért azt kell megvizsgálnunk, hogy a megfigyelendő jelenség (pl: tűz hatására bekövetkező anyagszerkezeti változás) kimutatható sürüségkülönbséget okoz-e.

\section{A CT ALKALMAZÁSA AZ ANYAG- VIZSGÁLATOK SORÁN}

A CT orvosi diagnosztikai alkalmazása ma már széles körben elterjedt, azonban az anyagvizsgálatok területén alkalmazásuk még egyáltalán nem, vagy kevésbé ismert. A CT a sürüség különbségek mérésére szolgál, ezért azt kell megvizsgálnunk, hogy az anyagvizsgálatok mely területén elegendő a sürüségkülönbség mérése, és mely tulajdonságok, illetve milyen anyagszerkezeti változások jellemezhetőek sürüségkülönbség-méréssel. Tekintettel arra, hogy az építőanyagok nagy része inhomogén, tehát található benne sürüségkülönbség, ezért anyagszerkezetük CT-vel jól vizsgálható. Továbbá az anyagszerkezeti leromlások során az anyagok sürüsége, szerkezete lényegesen megváltozik, ezért ezek a folyamatok is vizsgálhatóak CT segítségével.

Méréseinkhez egy harmadik generációs CT berendezést (Siemens SOMATOM Sensation 16) alkalmaztunk, amely a vizsgálat tárgyát egy sík, legyezőszerü röntgensugárnyalábbal világítja át.

A kutatás során komoly kihívást jelentett a CT-felvételek kiértékelése. A CT-felvételek zajossága miatt, a kiértékelés során képfeljavító eszközöket is alkalmaztunk. Ezek közé különböző szürők (például átlagoló szürő) tartoztak, továbbá külön foglalkoznunk kellett a CT-re jellemző nyalábkeményedési korrekcióval is.

A felvételeken a különböző sürüségü anyagokat szétválasztottuk, szegmentáltuk. A CT- felvételek feldolgozása és elemzése Matlab környezetben írt algoritmusokkal, automatikus módon, elöre beállított paraméterekkel történt.

A kialakított algoritmusok egyenként elvégzik a CTfelvételeken a szegmentálást, majd elemzés után előállítják a szeletenkénti, térfogatszázalékos statisztikákat. A módszer határai közé tartozik, hogy orvosi CT-vel a 0,4 mm alatti adalékanyag szemcsék nem szegmentálhatóak, ezek szegmentálása csak mikro vagy nano CT-vel oldható meg, de ez építőanyagok esetén ezek az eljárások a korlátozott minta méret miatt nem, vagy csak nehezen alkalmazhatóak.

\subsection{Aszfalt vizsgálata CT-vel}

Az aszfalt esetén a hézagtartalom jelentősen befolyásolja az útpályaszerkezet tartósságát. A hézagtartalom laboratóriumi körülmények között történő mérése nagyon költséges és bonyolult lehet. A hézagtartalom vizsgálata azonban a CTkészülékkel viszonylag egyszerü, hiszen a hézagok és az adalékanyag, illetve a bitumenhabarcs sürüsége jelentősen eltér egymástól. Aszfalt minta esetén a hézagtartalom-eloszlás alapján a réteghatárok is egyértelmüen azonosíthatóak (1. ábra), mivel a réteghatároknál a hézagtartalom jelentősen megnő. Ennek oka, hogy a burkolat készítésekor hideg aszfalt felületre meleg réteget visznek fel, és az összedolgozás során a két réteg között nagy hézagtartamú rész keletkezik (Lublóy, Ambrus, Kapitány, 2014), Fontos kérdés lehet, hogy a réteghatárokon mennyire növekedett meg a hézagtartalom. A laboratóriumi mérések során a próbatestek vizsgálata előtt itt történik a vágás és ezáltal a hézagtartalomban feldúsult részröl semmilyen információnk nem lesz, pedig az a rész adhatna információt a két réteg összedolgozásának állapotáról, és ezáltal a pályaszerkezet várható élettartamáról is.

Aszfalt esetén a hézagtartalom mellett a $4 \mathrm{~mm}$ feletti adalékanyagszemcsék is jól szegmentálhatóak, vizsgálható az adalékanyagok szem (cse?)alakja, illetve a térbeli eloszlása is.

\subsection{Beton vizsgálata CT-vel}

A beton vizsgálata bonyolultabb az aszfalt vizsgálatánál, mert az adalékanyag és a cementkő sürüsége nem tér el olyan jelentősen, mint az aszfalt esetén, így az adalékanyagszemcsék szegmentálása nehezebb feladat. Betonminta esetén a pórusok egyértelmüen azonosíthatóak és ezáltal megadható a próbatest póruseloszlása is. Nagyon fontos, hogy a beton esetén a pórustartalom viszonylag könnyen és egyértelmüen meghatározható, hiszen ez a tartóssági kérdéseknél nagyon fontos. Itt azonban meg kell jegyezni, hogy a mikropórusok vizsgálata, ami a fagyállóságot jelentősen befolyásolja csak nagyobb felbontású mikro CT-vel lehetséges, ahol azonban a próbatestek mérete limitált ( $\mathrm{kb} 1 \mathrm{~cm}$ oldalhosszúságú kocka). Ez azonban a beton esetén kérdéssé teszi a releváns mintavétel lehetőségét.

Az anyagszerkezet vizsgálata esetén azonban a különböző leromlási folyamatokat is jól nyomon tudjuk követni CT segítségével. A 2. ábrán egy tűzkárosult betonból vett furatmagminta egy szeletét láthatjuk. A felvételeken jól

1. ábra: Aszfalt próbatest: az adalékanyag-, a hézag- és a kötőanyagtartalom eloszlása, valamit a réteghatárok azonosítása

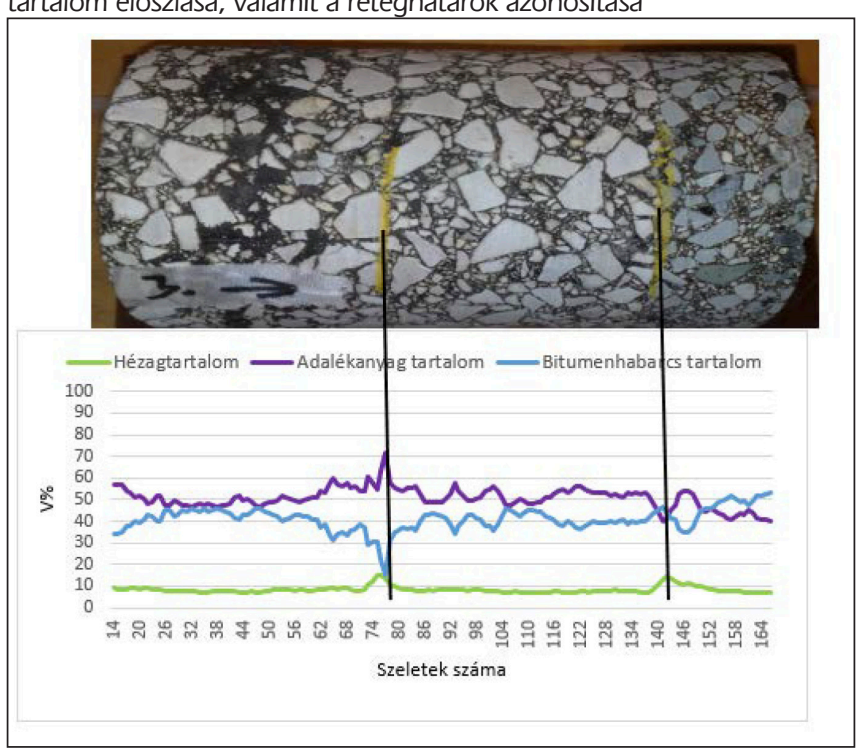




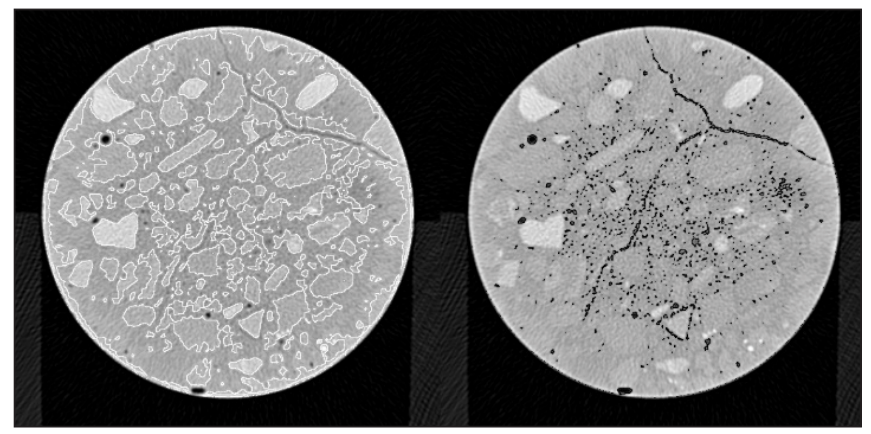

2. ábra: Beton próbatest: az adalékanyag- (fehér körvonal) és pórusrendszer (fekete körvonal) a CT rétegfelvételeken

látszanak a kialakult repedések. A 3. ábrán megadtuk az adalékanyag-tartalmat, a habarcstartalmat és a pórustartalmat a minta hossztengelye mentén. A görbéken látható csúcsok azzal magyarázhatóak, hogy a szeleteken belül eltérő lehet az adalékanyag- és a habarcstartalom. Jól látható, hogy a 100 jelü szelettől a porozitás megnő, ezért a pórustartalmat külön is ábrázoltuk. A 3. ábrán látszik, hogy a beton felület felső 100 mm vastagságú része károsodottnak tekinthető, ami szilárdságcsökkenésre utal.

A 4. ábrán falpanelelemek láthatóak a tüzvizsgálat után. A falpanelelemeken a betonfedés levált. A betonfedés leválásnak oka a beton nagy szilárdsága (C 30/37) és az alkalmazott cementtípus (CEM I 52,5 R) volt.

A tüzvizsgálat után a falpanel elemekből magmintát vettünk. A mintavételezés során ügyeltünk arra, hogy a mintákat a jellemző helyekről vegyük, ezért az alsó elemből, ami a legjobban károsodott, négy magmintát, a középső és az alsó elemből 2-2 mintát vettünk. A mintákat CT-vizsgálatoknak vetettük alá. A CT-vizsgálatok eredményeit az 5. ábrán adjuk meg. Az oszlopdiagramon a magmintákon mért HU értékek átlagát adjuk meg. Az oszlopdiagram alapján megállapíthatjuk, hogy a károsodás mértéke összefügg a meghatározott HU értékkel. A jobban károsodott részen egyértelmüen csökkent a HU érték. Ezek alapján megállapítható, hogy abban az esetben is, ha a betonfelület levált, a tüzterhelést, illetve a károsodás mértékét meg lehet határozni CT-mérések segítségével.

Szálerősítésü betonok esetén nagyon fontos a szálak elhelyezkedése, hiszen ez befolyásolja a szerkezet teherbírását. A száltartalom és a keverési idő szálorientációra, szálelhelyezkedésre való hatásának vizsgálatához $\mathrm{CT}$ vizsgálatot végeztünk szálerősítésü betonokon (6. ábra). A CT vizsgálatot a száladagolást követően 5 percig kevert, 0.3 V\% száltartalmú, illetve 0.5 V\% száltartalmú keverékből és a

\section{3. ábra: A pórusok eloszlása az egyes szeleteken belül}

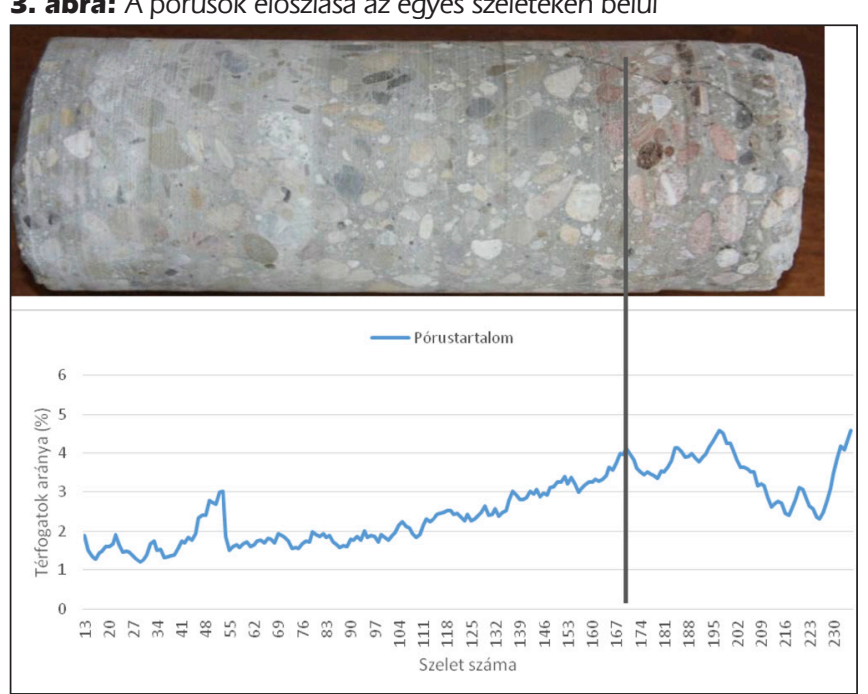

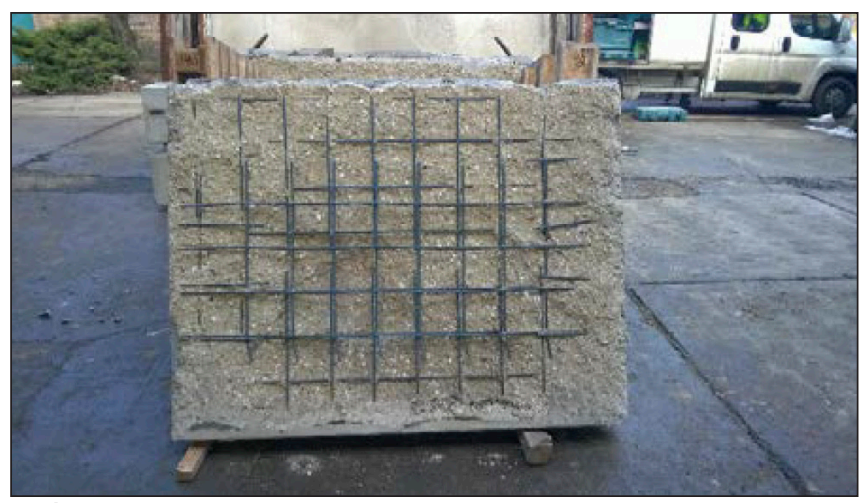

4. ábra: Az alsó falpanel elem károsodása a tűz után

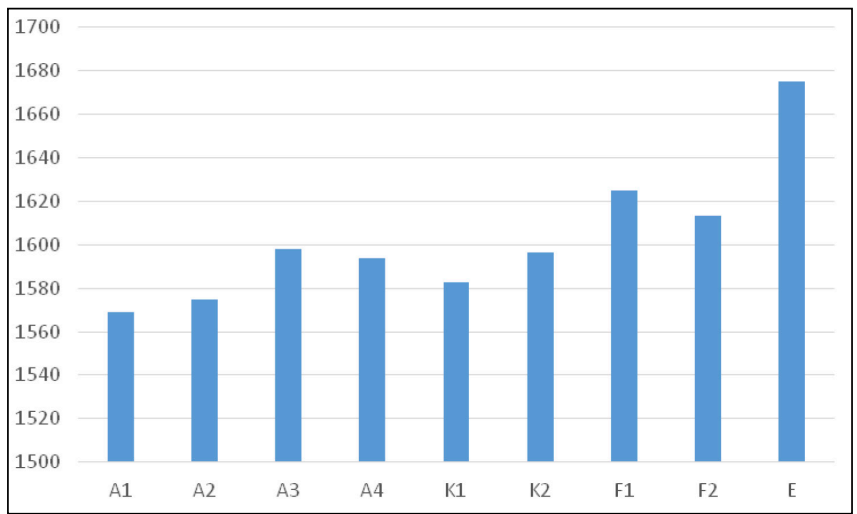

5. ábra: A magminták átlagos HU értéke a falpanelelemekből kifúrt mintákon (A alsó panelelem, K középső panelelem, $\mathrm{F}$ felső falpanelelem, E tüzterhelés nélküli panelelem)

száladagolást követően 30 percig kevert, 0.5 V\% száltartalmú keverékből készült 1-1 db félgerendán végeztük.

A CT felvételék alapján a következőket figyeltük meg:

A száltartalomm változtatásának nem volt jelentős hatása a szálelhelyezkedésre. A szálak betonban való hosszabb keverési ideje ( 5 perc helyett 30 perc) egyenletesebb száleloszlást eredményezett, azonban nem szüntette meg teljesen a lokális szálfeldúsulásokat.

- A szálak irányultságát jelentősen befolyásolta a betonba adagolt szál mennyisége. A nagyobb (0.5V\%) száltartalom esetén a szálak már rétegesen irányítottá váltak.

- Vizsgálataink során kimutattuk, hogy 150×150×600 mm élhosszúságú próbatestek zsaluzott oldalain a szálak a zsaluzat irányába rendeződtek, míg a próbatest közepén véletlen irányultságúak voltak.

- A szálirányultságra nem volt jelentős hatása a keverési idő változtatásának. Jelentős hatása volt azonban a bedolgozásban, illetve a tömörítésben végzett kisebb változtatásoknak.

- Kimutattuk, hogy az acélszálak egy része a betonban való keverés hatására deformálódhat. A deformáció mértéke és gyakorisága csak kis mértékben növekedett a hosszabb (5 perc helyett 30 perc) keverés hatására (Balázs, Czoboly, Lublóy, Kapitány, Barsi, 2017).

\subsection{Vasbeton víznyomócső vizsgálata}

Vasbetonszerkezetek esetén fontos, hogy az acélbetétek korróziós állapotáról lehetőség szerint a legtöbb információt kapjuk. Az acélbetétek állapota, amiről csak a betonfedés eltávolítása után tudunk nyilatkozni, különösen fontos a későbbi teherbírás megítélése szempontjából. Jelen kutatás során kérdés volt, hogy mi található a már szemmel is 


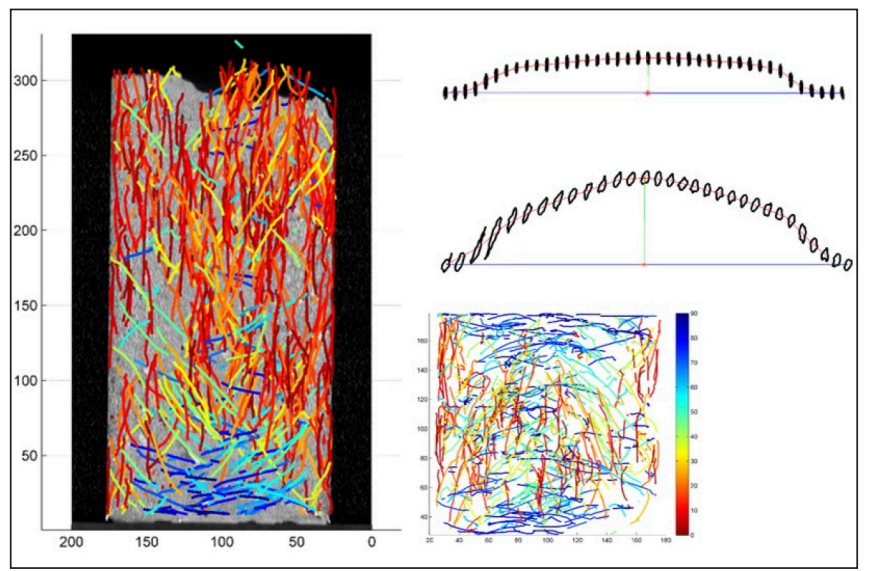

6. ábra: Az acél szálerősítésű betonok száleloszlás elemzése CT-vel

látható rozsdafoltok alatt. A CT felvételen jól látható, hogy az acélbetétek elszakadtak (7. ábra). A nagy rozsdafolt alatt a beton károsodását (kiüregelődését) is megfigyeltük. Az üreg közvetlen környezetéről felvételeket készítettünk. Megállapíthatjuk, hogy az acélbetétek környezetében kisebb sürüségű rész látható, valószínüleg ez okozta a károsodást. A 7. ábrán az elszakadt acélbetétek keresztmetszetét is láthatjuk. A felvételeken megfigyelhetö, hogy az acélbetétek közepén kiüregelődés jött létre (Czoboly, Lublóy, Balázs., Zimmer, 2014).

\subsection{Azbesztcement vízcső vizsgálata}

További kérdés, hogy más építőanyagok anyagvizsgálata, illetve leromlásának feltérképezésére is alkalmas-e a CT? Jelen kutatásban a vízvezetékek ismert cső típusát, az azbesztcement csöveket vizsgáltuk.

A 8. ábrán az azbesztcement csőről készült komputertomográfiás felvétel látható. A CT felvételen a károsodott helyen a cső teherbíró részének elvékonyodása tapasztalható (8.a. ábra). A CT-felvétel színeinek módosítása után jobban érzékelhető az árnyalatok közti különbség, így a levált felület is jól elkülöníthető a CT-képeken, úgy ahogy a metszetről készült fényképfelvételen is. A 8.a. ábrán a világosabb színek a magasabb Hounsfield-értékü (sürüségü) területeket adják meg, a sötétebb részek pedig az alacsonyabb sürüségű részeket. A sürüségcsökkenésből mindig valamilyen anyagszerkezeti leromlásra következtethetünk.

A 8.b. ábrán a károsodott rész környezetét láthatjuk. Jól látszik, hogy a károsodott rész sürüségértéke jelentősen csökkent. A sürüségcsökkenés nem egyenletesen következik be, hanem rétegesen. Ez a réteges sürüségcsökkenés magyarázza a tényt, hogy más roncsolásmentes vizsgálat elég nehezen végezhetö.

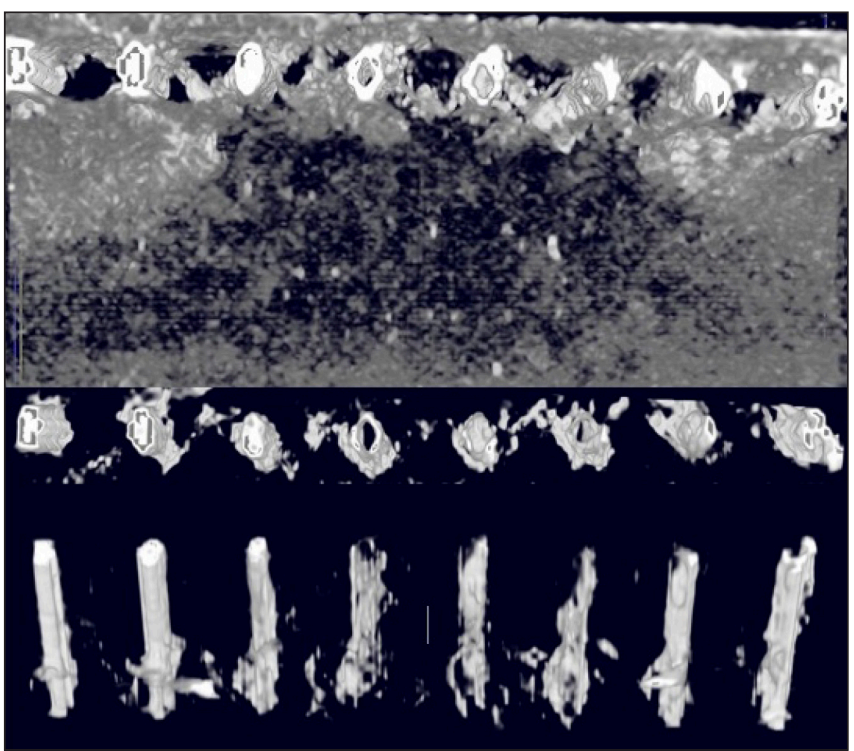

7. ábra: A Sentab csövek vizsgálata CT-vel

\section{4. ÖSSZEFOGLALÁS}

Jelen cikk keretein belül röviden áttekintettük, hogy a CTvizsgálatok hogyan használhatóak célszerüen az építőanyagok vizsgálataihoz.

Vizsgálataink sorába tartoztak aszfalt, beton, vasbeton és azbesztcement elemek.

A kutatások eredményeink alapján megállapíthatjuk, hogy a

- CT alkalmas a porózus építőanyagok belső szerkezetének feltérképezésére, természetesen a mérés során alkalmazott szeletvastagság és képi felbontás figyelembevételével, az ott létrejövő korlátok betartása mellett;

a CT alkalmas az anyagokban bekövetkező szerkezeti változások (leromlás) nyomon követésére;

a CT alkalmas az acélbetétek korróziós állapotának megítélésre a betonfedés eltávolítása nélkül.

\section{KÖSZÖNETNYILVÁNÍTÁS}

A cikk szerzői köszönetet mondanak az NVKP_16-1-0019 “Fokozott ellenálló képességü (kémiai korróziónak ellenálló, tüzálló és fagyálló) beton termékek anyagtudományi, kísérleti fejlesztése" címü pályázaton keresztül kapott kutatási támogatásért.

\section{)}

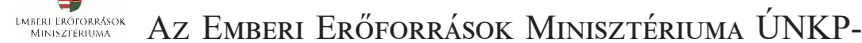
18-4 kódszámú Új Nemzeti Kiválóság Programjának támogatásával készült.

8. ábra: Azbesztcement cső CT vizsgálati eredményei (a. Keresztmetszet, b. A károsodott rész környezete)
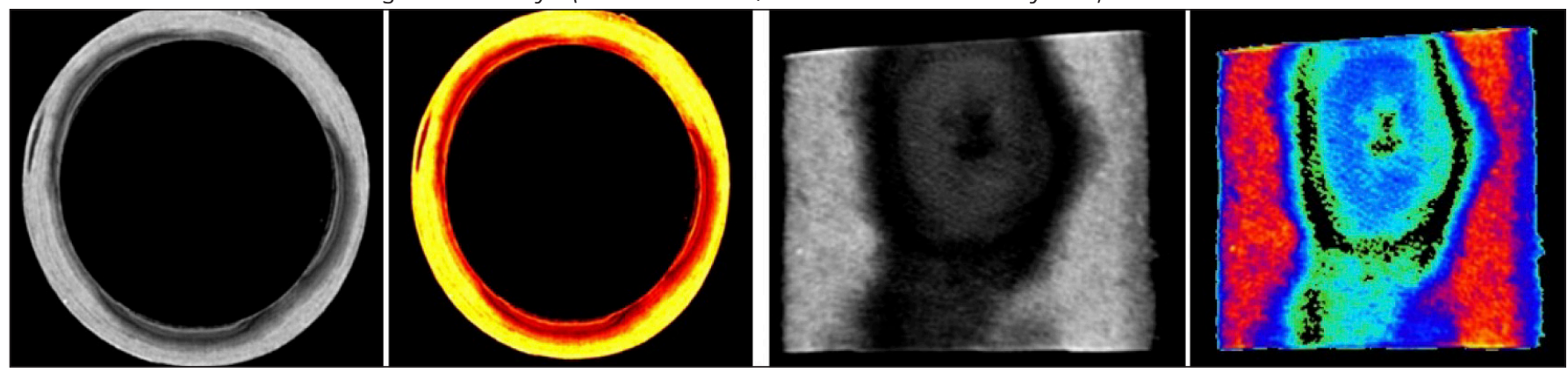


\section{HIVATKOZÁSOK}

Balázs, L. Gy., Czoboly, O., Lublóy, É., Kapitány, K., Barsi, Á. (2017), „Observation of steel fibres in concrete with Computed Tomography”, Construction and Building Materials 140, pp. 534541., https://doi.org/10.1016/j.conbuildmat.2017.02.114

Berényi E., Bogner P., Horváth Gy., Repa I. (1997), Radiológia. Springer Hungarica, Budapest, 1997 Buzug, T. M. (2008), „Computed Tomography - From Photon Statistics to Modern Cone-Beam CT”, Berlin/Heidelberg : Springer-Verlag, 978-3540-39407-5.

Czoboly O., Lublóy É., Balázs L. Gy., Zimmer P. (2014), „Leromlási folyamatok Sentab Típusú nagy átmérőjü feszített vasbeton nyomócső esetén", Konferencia Kiadvány, XVIII. Nemzetközi Építéstudományi Konferencia: ÉPKO 2014. Csíksomlyó, Románia, 2014.06.12-15, Kiadó Erdélyi Magyar Műszaki Tudományos Társaság (EMT) Kolozsvár, pp. 46-49.

Földes T. (2011) Kőzetkarakterizáció röntgen computer tomográf(CT) mérésekkel végzett hidrodinamikai vizsgálatokkal, Újdonságok a geotermikában: Geotermikus koordinációs és innovációs alapítvány időszakos kiadványa, pp. 25-42.

Lublóy É., Ambrus D., Kapitány K. (2014), „Aszfalt összetétel vizsgálata CT-vel”, Konferencia Kiadvány, XVIII. Nemzetközi Építéstudományi Konferencia: ÉPKO 2014. Csíksomlyó, Románia, 2014.06.12-15, Kiadó Erdélyi Magyar Müszaki Tudományos Társaság (EMT) Kolozsvár, pp. 186-189.

Russ, J. C. (2011), „Image Processing Handbook”, Book, Sixth Edition, ISBN: 1-4398-4045-8, CRC Press

Dr. Lublóy Éva (1976) okl. építőmérnök (BME Építőmérnöki Kar, 2001), docens a BME Építőanyagok és Magasépítés Tanszékén (2008). Fő érdeklődési területei: vasbetonszerkezetek viselkedése tüz hatására, tủzkárok mérnöki tanulságai. A fib Magyar Tagozat tagja.

Dr. Balázs L. György (1958) okl. építőmérnök, mérnöki matematikai szakmérnök PhD, Dr. habil., egyetemi tanár, a BME Építőanyagok és Magasépítés Tanszék vezetője. MTA müszaki tud. kandidátusa. Fö kutatási területei: beton, vasbeton és feszített vasbeton szerkezetek (anyagai, laboratóriumi vizsgálata és modellezése), roncsolásmentes vizsgálatok. Speciális betonok és betétek: szálerősítésủ betonok (FRC), nem acélanyagú (FRP) betétek, megerősítések anyagai és módjai, HPC, UHPC, LWC. Túzállóságra való tervezés, tüzállóság fokozása. Fagyállóság fokozása. Kémiai ellenálló-képesség fokozása. Tartósság. Használati élettartam. Fenntartható építés. Erőátadódás betonban, vasbeton tartók repedezettségi állapota. Fáradás. Lökés szerü terhelés. Nukleáris létesítmények. A fib (Nemzetközi
Betonszövetség) elnöke (2011-2012), jelenleg tiszteletbeli elnöke. A fib Magyar Tagozat elnöke. Az Int. PhD Symp. in Civil Engineering alapítója. A fib Com 9 „Dissemination of knowledge” elnöke.

Földes Tamás (1954) okl. geológus (ELTE 1979), 2005-ig a Köolajkutató vállalatnál, majd pedig a MOL Rt-nél dolgozott. 2006-tól a Kaposvári Egyetem Diagnosztikai Intézetének munkatársa. 1999-töl végez CT és MR mérési értékeléseket élettelen vizsgálati anyagokon, elsősorban kőzeteken. Fő érdeklődési területe: szénhidrogén rezervoár, geológiai modellezés, nagyfelbontású képalkotó roncsolásmentes mérések (CT, microCT, MR), élettelen anyagvizsgálati módszerek kiértékelése. A Magyarhoni Földtani Társulat, a Geofizikai Társulat és az EAGE tagja.

Dr. Kapitány Kristóf (1987) építőmérnöki (térinformatikus) BSc (BME Építőmérnöki Kar, 2009), Földmérő- és térinformatikai mérnök MSc (BME Építőmérnöki Kar, 2012), PhD hallgató a BME Fotogrammetria és Térinformatika Tanszékén. Fő érdeklődési területei: képfeldolgozás, orvosi képalkotás, objektumrekonstrukció orvosi képekböl.

Hlavička Viktor (1987) okl. szerkezetépítö-mérnök (MSc), betontechnológus, tüvédelmi tervezési szakmérnök, a BME Építőanyagok és Magasépítés Tanszék doktorjelöltje. Fő érdeklődési területei: rögzítéstechnika, mechanikus és ragasztott csapok betonokban való viselkedése és végeselemes modellezése, tüzkárosult szerkezetek és szerkezeti anyagok mérnöki tanulságai. A fib Magyar Tagozat tagja.

\section{POSSIBILITY OF APPLICATION OF CT IN CASE OF BUILDING MATERIALS}

Dr. Éva Lublóy - Dr. György L. Balázs - Tamás Földes - Dr. Kristóf Kapitány - Viktor Hlavička

Keywords: material testing, CT, material structure, non-destructive testing

Detailed information on the internal structure of building materials is highly important for us, as it highly affects properties and durability of materials. Some information about the internal structure can only partly be obtained by analytical methods.

Images generated during a computer tomograhic (CT) scanning are able to show sections of the specimens. The images that are constructed by a data matrix show the density distribution of the material tissue. Elements that have different density are visually separated and, therefore, can be clearly identified. If the sections are displayed in a line then the internal structure can be visualized in 3D. 